\title{
Not on Bread Alone Doth Man Liveth (Deut. 8:3; Mat 4:4): Some Iconoclastic Views on Populism, Democracy, the Rule of Law and the Polish Circumstance
}

\author{
Joseph H. H. Weiler
}

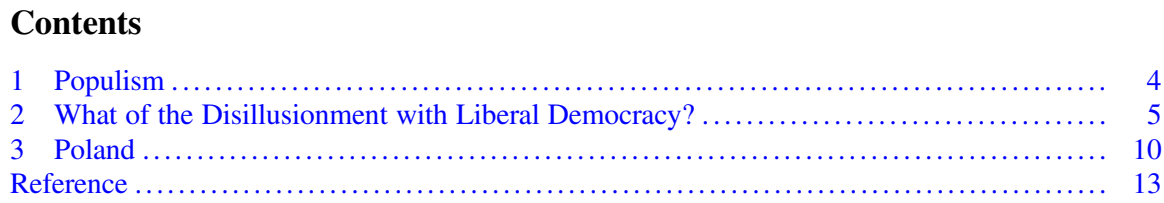

\begin{abstract}
Polarization in today's politics, pre- and post COVID, transcends nations, states regions and continents. It's a feature of politics which, in and on itself, when played to extremes by demonizing one's opponents, it threatens democracy itselfsince it frays the demos some cohesion of which is necessary for the legitimacy of majoritarianism, one of the pillars of national democracies. Its lexical manifestation is to be found with expressions such as 'traitors' or 'not real' Americans, Italians, Israelis - take your pick and fill in the gap.

It has, lamentably in my view, a spillover effect also into the academic world of scholarship. A word of criticism of, say, the European Court of Justice instantly brands you a 'Eurosceptic' and one of 'them'. To speak of Universal Values, casts you as an enemy of this or that national cause. This is not to say, not at all, that one cannot bring to one's scholarship a fully engaged normative and ethical commitment, especially in the field of law which has, or should have, at its roots a commitment to justice. But it militates against careful listening, complex reasoning and understanding and more fine grained normative judgments. Justice is oftentimes not black and white.

It is particularly so when it comes to dealing with the phenomenon of Populism which has moved from the fringe to the center of politics. Trying to understand Populism is not akin to justifying it.
\end{abstract}

\footnotetext{
J. H. H. Weiler ( $ه)$

New York University, New York, NY, USA

e-mail: weilersoffice@nyu.edu
} 


\section{Populism}

I despise the word Populism. When you like them, (Tzipras in Greece or Podemos in Spain perhaps?) they are Popular. When you dislike them, they are Populist. But this is just the beginning. In a political circumstance which requires discernment and careful judgment in arriving at moral and political conclusions, 'Populism' is a broad and lazy paintbrush which colors everyone with the same damning color and allows one to feel virtuous, basking in one's own self-righteousness. Salvini, Hungary, Marine Le Pen, Poland, Brexiteers, AfD etc? They are all the same, are they not? Well, they are not, far from it. It is as wrong as it is unhelpful.

'Populism' is a proxy for two judgmental sentiments: 'They' are either fascists, or at best crypto-fascists, whom you can thus just write off and consign to the beyondthe-pale waste bin, (which is appropriate for those who are truly so!) And/or, they are (resorting to that odious Marxist trope of False Consciousness) simply dumb. 'They' do not get it, if only they understood...Yes, there are among them quite a few which are both, but I refuse to accept that millions of Europeans, in Member States from East to West, from North to South, are either dumb or have become in short order fascists.

Be that as it may, there is a deep self-exculpatory streak in the simplistic narrative concerning those 'awful populists'. It exculpates us, the bien pensants of the Post WWII political and moral comfort zone which extends between Christian Democracy and Social Democracy and an ironclad commitment to European integration. It obviates the necessity of some serious soul searching of what in the established political order has led to this major, non-peripheral rupture in the European consensus and to examine, what if anything is our responsibility for such.

The two principal sins of the 'populists' is a growing Euroskepticism and a disillusionment with the fundamentals of the liberal democratic order.

I hope my credentials are such that my lifelong commitment to the European construct will not be called into question nor, my old fashioned liberal commitment. When it comes to Europe, this enduring commitment is rooted not only or even principally in the material and utilitarian benefits of such, but in the deep moral and even spiritual dimensions of the construct_aimed at forging a different kind of human relations among peoples divided by borders: Nous ne coalisons pas des Etats nous unissons des hommes. And the commitment to liberal democracy (which in Europe can cover the gamut from Socialism, through social democracy, through liberalism, Christian Democracy including democratic social conservatives) is to be considered as the oxygen of our shared political life.

But we cannot turn a blind eye to some major fault lines in the construct which contradict its most cherished values. Despite the full empowerment of the European Parliament European democracy remains deeply flawed. The two most primitive features of democracy, which cut across the rich variety of specific arrangements in our Member States, are the ability of the electorate, through parliamentary elections (in this case elections to the European Parliament) to determine, or have a decisive weight in deciding, by whom we will be governed, and, at least in a broad way, what 
will be the ideological and policy direction by which we will be governed. It is not comfortable to admit, but European democracy fails on both grounds. The first point was painfully visible in relation to electing the current incumbent heading the Commission (like her predecessor I think she is an impressive incumbent, but this is beside the point); and over the years we have come to realize that voter preference in the outcome of such elections has had a tenuous connection to the policies of the Union. Our system does not allow European citizens to feel, even in relation to these two primitive parameters, that they have any appreciable impact on the governance of the polity.

It should surprise no one that the slogan, iterated in different forms by Eurosceptics, Taking back Control, had and has so much resonance. The resulting alienation is not simply understandable but in no small measure justified.

These defects of the political process give added weight to the importance of the European Court of Justice and the European legal order. It is not perfect, far from it; I have published from time to time trenchant critiques of some of its judgments and certain aspects of its modus operandi. ${ }^{1}$ But it is fiercely independent in its spirit and self-understanding, does not kowtow to Member State government interests and has placed the individual and his or her rights squarely in the center of its juridical sensibilities. It is not only the de facto constitutional court of the Union, but more than Brussels, Luxembourg epitomizes the meaning that may be given to European citizenship. The Court might infuriate us from time to time. If the motto of the EU is United in Diversity, in its jurisprudence it might have, in the eyes of some, given more weight to United than to Diversity. One could argue that it would be well advised to foster a veritably more dialogical process with its Statal judicial interlocutors. But the way to change, if change is needed, is through constitutional channels. If the authority of and the loyalty to the European Court of Justice were to be seriously undermined, it would not only be a blow to the rule of law in the transnational arena for which Europe is the world leader, the very European construct as a space of justice would be threatened.

\section{What of the Disillusionment with Liberal Democracy?}

The 'Holy Trinity' of the liberal order are Democracy (free elections and majoritarian rule), Human Rights and the Rule of Law. I use the term 'Holy Trinity' only with limited irony. Since, like the real Holy Trinity, the three are one: Majority governance without the constraints of human rights and the rule of law is but a tyranny of the majority. Human rights without effective rule of law are but slogans. The rule of law, outside a democracy is simply the most effective instrument of authoritarianism and worse. That is why so called 'illiberal democracy' is an oxymoron. It is no democracy at all.

\footnotetext{
${ }^{1}$ See for example https://www.ejiltalk.org/je-suis-achbita/.
} 
There is a second sense in which I use the metaphor of 'Holy Trinity'. These three values represent the bedrock of our civil faith, the reason we fought to overturn both fascism and Communism in the twentieth Century.

But whence, then, the disillusionment with these noble values?

It is oft forgotten that these are peculiar values in the sense that they are mostly but conditions for the Good Life (in the ancient Greek and Biblical sense). Democracy is a 'technology' of governance, flawed but the best we have. But it gives no instruction as to the content that has to be put in place in the act of governance. A democracy of evil people will be an evil democracy even if enjoying majoritarian support, does not violate human rights and respects the rule of law. Human Rights guarantee our liberties but give no instruction as to how one should exercise such liberties. One can use freedom of expression, for example, to be vile. One can be mean spirited, egoistic, hard hearted and lacking in charity and mercy and yet not violate anyone's human rights. And provided our laws do not violate fundamental human rights, they too, can be uncaring, socially unjust, draconian and yet the rule of law would still be observed.

In this sense, then, the 'Holy Trinity' are but a framework to be filled. They are like the oxygen of physical life. You need it to live, but it does not determine how your life will be lived.

What has been, generally speaking, the governance policy content that has been put into this framework in the Post WWII decades by the European political consensus, and what has been left out?

It has been primarily material: Prosperity. The Treaty of Rome expresses this enduring concern very well: The [European] Community shall have as its task, by establishing a common market and progressively approximating the economic policies of Member States, to promote throughout the Community a harmonious development of economic activities, a continuous and balanced expansion, an increase in stability, an accelerated raising of the standard of living and closer relations between the States belonging to it.

The Treaty of Nice further elaborated this concern by stating: The Community shall have as its task, by establishing a common market and an economic and monetary union and by implementing common policies or activities referred to in Articles 3 and 4, to promote throughout the Community a harmonious, balanced and sustainable development of economic activities, a high level of employment and of social protection, equality between men and women, sustainable and non-inflationary growth, a high degree of competitiveness and convergence of economic performance, a high level of protection and improvement of the quality of the environment, the raising of the standard of living and quality of life, and economic and social cohesion and solidarity among Member States. ${ }^{2}$

\footnotetext{
${ }^{2}$ Treaty establishing the European Community (Nice consolidated version), Article 2, Official Journal C 325, 24/12/2002 P. 0033—0184, Official Journal C 340, 10/11/1997 P. 0173—Consolidated version.
} 
The magic square of development of economic activities, expansion (growth), increased stability (low inflation) and raising standard of living - the Canon of OrdoLiberalism - has been the bedrock of European politics for decades. This is mainly what the main parties argue about - the best way to achieve such: Fiscal austerity or otherwise and how much? And what policies of redistribution are the best to ensure prosperity with social justice. There are some notable theorists of democracy who claim that the essence of democratic governance is but the issue of redistributive politics. Christian democracy and social democracy, until recently occupying the central space of European politics shared this same bed.

Our record in this sphere is both spectacular and dismal. These politics, the different political divisions between the center left and center right notwithstanding, has resulted in remarkable overall growth in prosperity and the European construct has played a critical role in such. But these politics, the different political divisions between the center left and center right notwithstanding, has also seen a remarkable growth in the uneven distribution of the deserts of this political project and of, more recently economic globalization. It is a common place that as a result of this gap, a growing segment of the population has felt left out of this success story.

A blind spot of Ordo-liberalism which under different guises and labels has so dominated our political landscape is that it regards the human person, in as much as politics is concerned, as Homo Economicus. But Not on Bread Alone doth Man Liveth. When one, explicitly and implicitly, places Prosperity at the center of your politics, one is transmitting a value, a measurement of 'worth' and of Respect. Just think of the respect that is accorded those States that 'make it' in these terms: The Germanys and Americas and Switzerlands of this world. And the same becomes true at the social and individual human level. The gap thus produces not only a resentment at the material unequal distribution of prosperity, but a deep sense of 'not making it' in a society which values 'making it' above all, an attendant sense of disrespect.

One cannot overstate the centrality of respect (and the lack of it) to human wellbeing. If we consider how, in Europe, in our various constitutions and charters of rights we have placed the inviolability of dignity as our primary human right, one can understand how potent will this disrespect be, real and perceived, in the political arena. The sense of material inequality pales in comparison to the sense of dignitarian inequality and deprivation. It is no answer to say that personally one does not disrespect persons because of their economic condition, if the system, as a whole, privileges so much material well-being and prosperity.

Our centrist politics are characterized not only by what has been placed at the center but by what has been removed.

In the critique of liberalism by such as Michael Sandel and Michael Walzer to name but two, a central argument concerns the very focus of liberalism on the individual and his or her liberties. Yet, the human person is always 'situated', sociality is integral to the sense of self. And I would add I would postulate-that as part of the very human condition there is a quest to give 'meaning' to one's life in the sense that the sum of one's existence not be limited to self-betterment-the engine of the free market-but will have some meaning that transcends such. And 
indeed it is the social condition that often provides this because it is only in sociality that altruism may be practiced and experienced. Moreover, the social situates the individual within a collective identity; it is commonplace that it is the collective identity which contributes to the sense of meaning that goes beyond the self.

In the pre-War era the two institutions which were most prevalent in this respect were national patriotism and religious faith. People found deep meaning in both. It is important to state, immediately, that the understanding of both is not exhausted, not even remotely so, by the meaning that was given to them in that era.

For reasons that are quite understandable, the very word 'patriotism' became 'unprintable' after the War notably in Western Europe. Fascist regimes (among others), by abusing the word and the concept, had 'burned' it from our collective consciousness. And in many ways this has been a positive thing. But we also pay a high price for having banished this word - and the sentiment it expresses-from our psycho-political vocabulary. Since patriotism also has a noble side: the discipline of love, the duty to take care of one's homeland and people, of one's neighbour; of accepting our civic responsibility toward the community in which we live. In reality, true patriotism is the opposite of Fascism: 'We do not belong to the State as fascism claims; it's the State that belongs to us' and we are responsible for it and what happens to it which is the essence of democratic republicanism.

But the baby-a liberal and enlightened sense of national belongingness and pride - was thrown out with the bathwater of pre-War odious atavistic nationalism.

For reasons which I will not elaborate here, Europe, with probably the exception of Poland and a handful of others, underwent in the post war politics a rapid process of secularization. Not only did Laicite become prevalent and normative, but with time it has, as I argue in my book A Christian Europe ${ }^{3}$ been accompanied by distinct Christophobic manifestations.

This is obviously not a call for evangelization. I never judge a person by their faith or lack of it. I know religious persons who are awful human beings and atheists who are noble. But as a society we have paid two heavy prices for this process. First, we have lost a voice which was at one time universal and ubiquitous. A voice in which the emphasis was on duty and responsibility and not only rights, on personal responsibility in the face of what happens to us, our neighbours and our society. It has been replaced by an instinctive appeal to public institutions as both the source of all ills and as the remedy. In Church you do not hear about your entitlements from the State and others but on your duty towards society and others. No politician today in Europe could or would repeat the famous Kennedy Inauguration speech of 1960 - Don't ask what your country can do for you but what you can do .... Etc. The Citizenship chapter of the European Treaties are a poignant example. They speak of rights and duties which the citizen enjoys and owes-but then no duties are ever mentioned.

Duty and responsibility - towards others and not only ourselves and our families-are empowering as citizens and human beings. They, like identity, are meaning

${ }^{3}$ Weiler (2004). 
giving. And, of course, with a laique culture which consigns religions to the private sphere at best, and disdains it at worst, those to whom religion is an important point of reference feel marginalized, at times disrespected and under (non physical) threat.

Our commitment to rights, as has been pointed out by many is not, too, without ambiguities. We've accepted, both at the national and international levels, a serious and irreversible obligation rooted in our Constitutions to protect the fundamental rights of individuals, even against the political tyranny of the majority. At a more general level, our political-juridical vocabulary has become a discussion of legal rights. The rights of, say, a German citizen are protected by our Courts, and, above all, by the Constitutional Court. But also by the Court of Justice of the EU in Luxembourg, and - again — by the European Court of Human Rights in Strasbourg. It's enough to make your head spin. And this is true for the other Member States.

Just think about how common it has become, in the political discourse of today, to speak more and more about 'rights.' To try and turn any political action into a legal action about rights, and entitlements. And using the courts, again and again, to achieve our political objectives. It's enormously important. I would never want to live in a country in which fundamental rights are not effectively defended. But here too-as with the banishment of patriotism—we pay a dear price. Actually, we pay two prices.

First and foremost, the noble culture of rights does put the individual at the center, but little by little, almost without realizing it, it turns him or her into a self-centered individual. It not only atomizes the individual since most fundamental right battles poses an individual and his or her liberties against the collective good but it also 'objectifies' him or her-as an object of someone else's power. The (justified) concern with human rights at the European level gives some cover to the loss of power resulting from our flawed democratic process.

And the second effect of this 'culture of rights'-which is a framework all Europeans have in common-is a kind of flattening of political and cultural specificity, of one's own unique national identity.

For the most part 'Identity' politics are considered an evil. And when identitarianism turns into atavism and worse, it is an evil. But Identity, individual and collective, like patriotism, have, too, a noble dimension. The notion of human dignity - (in the secular version it is part of human ontology; in the religion version it flows from the fact that we have been created in the image of God) contains, at one and the same time, two facets. On the one hand, it means that we are all equal in our fundamental human dignity: rich and poor, Italians and Germans, men and women, Gentile and Jew. To assign more worth to the life of one individual over another, is an assault on our dignity. On the other hand, recognizing human dignity means accepting that each of us is an entire universe, distinct and different from any other person. To treat any of us as fungible with others is an equal assault. And the same is true for each of our societies. To deracinate the cultural specificity of each of our nations and societies is, in this sense, to compromise an essential element of our dignity. When this element of diversity is diminished or derided, we rebel. 
And since with only small differences of nuance our supreme value as Europeans are our belief in the Holy Trinity of Rights, Democracy and Rule of Law (and thankfully this is the case) the specificities of our identities are seen to be devalued.

The 'Holy Trinity' remain indispensable, a 'sacred' dimension of our civil life. But I have argued that they are accompanied by a vacuum as regards the politics of meaning which I had ostulated as indispensable to the human condition.

The vacuum thus created has not been filled by mainstream politics, and the 'populist' turn at least in some appreciable measure has been a response to such. Of course it is tragic if the vacuum is filled by a return to pre-War versions of atavistic identity but the pretense that all is well if only the material needs of the human person are satisfied-as in Clinton's famous adage 'It's the Economy, Stupid' is terribly reductionist and as wrong in America as it has proven to be in Europe.

Mussolini understood this perfectly and his Family, Church, Nation slogan had immense mobilizing power for just this reason-it catered to the politics of meaning. But it has to be emphasized again and again_-different imaginaries exist. There can be, if we are to fasten on those three social institutions-and they are not the only ones-a concept of Patria and patriotism which is neither fascist nor atavistic but inclusive and celebrating diversity richness; there can be family which is not patriarchal but progressive and egalitarian and there are forms of our classical religions which are non-hierarchical but communitarian. This is not the place to elaborate on these but simply to remind us that a politics which and a social telos which reduces men and women to homo economicus are bound to produce the backlash we are experiencing today.

\section{Poland}

I turn now to Poland. The Polish narrative leaves few indifferent. Decades of oppression by both fascism and then Communism followed by liberation and impressive rejuvenation is a success story widely shared. Poland enjoys both high prestige and affection. It was Poland and the Polish who rocked the foundations of the Soviet empire and toppled the first domino which ended with the fall of the Berlin Wall. Who cannot feel deep solidarity, admiration and, yes, gratitude for Solidarnosc, for Tischner, for Wałęsa, for father Jerzy Popiełuszko and all the rest?

And the story of Poland in WWII-the heroism of Warsaw 44 is unique among those countries occupied by Germany. It was neither Paris or Rome or Amsterdam which rose in quite the same way and with quite the same cost.

And in more recent times, once liberated, who cannot but exclaim at the creativity and industriousness resulting in such rapid economic and political transformation, second to none?

I am not ignorant or oblivious to the shadows - we do not live in a society of saints and Poland is no exception; I am aware of the current critique of Polish democracy, both from within and without, some fully justified, some exaggerated, some outright fanciful. But Polish democracy endures. No one can fault the integrity 
of Polish elections themselves; the 2019 elections with power in the Senate changing hands is just one testimony to such. No one is afraid of a knock on the door in the middle of the night. There are no political prisoners languishing in camps or prisons. There is still a robust free media, traditional and social, as some counterweight to a government dominated public media, and the pro- and anti-government demonstrations are proof of an engaged citizenship, the life of a vibrant democracy. Yes, I detest the use of criminal sanctions in cases of alleged or real defamation, especially in the political arena. But I detest it as much in France as I do in Poland.

Can Polish democracy be better? Of course it can. Are there dangers and threats? There are. Should one be vigilant and engaged? One should. But this should not cloud one's overall judgment-which is far from black and white.

Do I agree with the policies of the current government? With some I do. I have, for example, sympathy for their concern for those segments of the population which suffered the unequal distribution of the deserts of the 'Polish economic miracle.' I also have sympathy for the legitimate concern to cherish that which is unique and special in Polish identity, including its Catholic heritage (though naturally I recoil when for some this legitimate and even essential value provides cover for vulgar expressions of xenophobia, homophobia and anti-Semitism). I do think the World needs educating on the suffering and heroism of Poland in WWII. The outrageous comments of Mr. Putin are particularly revolting in this context.

With other policies I do not. For example, government use of public media in the political arena is, against the American and British practice to which I am accustomed, alien to me and mars Polish democracy.

But I am always mindful that it is the democratically elected government of Poland, and it is well to remember that the discipline of democracy is such that one has to accept the discipline of democracy.

In my view the gravest threat to democracy in Poland and some other Western countries (the USA, Italy, Spain, Israel and others) is, as noted above, a polarization of society which goes beyond the normal divisions between strongly held views of, say, Left and Right. A polarization which entirely delegitimizes one's political adversaries, considers them as betraying the patria and worse. This not only stifles civic discourse it also fractures the demos; a sense of shared destiny, beyond political divisions is essential to democracy. The word Demos in democracy is not a lexical artifact. It is an ontological necessity for a functioning democracy. This imposes a duty, easier to preach than to practice, to moderate the tones of contentious political discourse for both sides and to realize that once a certain line has been crossed it is extremely difficult to pull back. Lack of restraint on one side feeds the same on the other and the vicious spiral just deepens.

But when it comes to the Rule of Law one cannot but lament some of the measures recently introduced. One should not get the impression that the functioning of the Polish judicial system pre 2015 was a bed of roses. Voices both of the left and right of the political spectrum identified serious flaws which called for reform. But the manner in which this reform has been taken has been, in my view, impatient, short sighted and damaging in the long term to one of the foundations of democracy. 
There is no need to list these measures, the principal ones of which have been the subject of litigation and already condemnation by the European Court of Justice.

I say this for several reasons.

Politics have some role in the appointment of the judiciary, and different countries manage such in different ways. In the United States some State judges are selected by a popular vote on election day. A terrible system. And appointments to the Supreme Court have become a highly charged political battle, an example for no one. One better look to, say, Italy or Germany for more thoughtful and politically balanced systems. Be that as it may, once appointed, the independence of the judiciary becomes, for obvious reasons, the bedrock of the Rule of Law. Judicial misconduct such as bribe taking has of course to be dealt with, including eventually by criminal sanctions. But objectionable judicial decision making is to be dealt with through the judicial appeal process. Disciplinary proceedings affect directly the kind of judicial independence in deciding a case essential to the judicial function. A threat is no different from a bribe. I think this point has been made sufficiently and I do not need to add. But there is one dimension which troubles me beyond the intrinsic point. Poland is a democracy which means that sooner or later, as in all our European democracies, a new party and a new government will come into power. It would be a disaster, if the practice were established, that each new government would feel it had a license to reshape the judiciary to fit its own sensibility. The damage, thus, is not simply to the immediate independence of the judiciary but to the long term culture of judicial independence. Democrats in the USA might be furious with judicial appointments made during a Republican administration and no less so with decisions of judges so appointed. And vice versa, of course. But both sides would consider it anathema to seek to touch those sitting judges precisely for realizing that the principle of judicial independence in the political culture of the nation is in the long term more important than a short terms gain in, say, the manner of appointing or disciplining judges. Self restraint and patience are the only viable approach to this dilemma if the essential balance between democracy, human rights and the rule of law is compromised. The rule of law and the independence of the judiciary is what stands between democracy and the tyranny of the majority.

There has also been enough discussion on the ill will towards Poland which the various judicial reform plans have generated, even among firm friends of Poland. Seen from the outside, Poland is paying an increasingly heavy reputational price for a project which is intrinsically flawed.

But here, too, I want to add, with humility, a point which has received somewhat less attention. I have already expressed, in word and deed, my sympathy for a country such as Poland which wants to hold on to its Christian identity respecting at the same time, in the European tradition, full freedom of religion and freedom from religion. In some ways it is one of the few remaining countries in Europe which is serious about such and certainly the most important. It is the embodiment of JPIIs encyclical Centesimus Annus, a foundational document of the twentieth Century, which argued persuasively the manner in which Christianity and democracy are not antagonists. This is not only important for Poland but for Europe as a whole. This places a special responsibility on the State. There are certain lines which Poland 
crosses not only compromise the reputation of Poland but the perception of the viability of the Centesimus Annus proposition to the detriment of European civilization.

\section{Reference}

Weiler JHH (2004) Ein christliches Europa: Erkundungsgänge. Verlag Anton Pustet, Salzburg

Joseph H. H. Weiler is serving as European Union Jean Monnet Chair at New York University Law School and Senior Fellow of the Minda de Gunzburg Center for European Studies, Harvard.

Open Access This chapter is licensed under the terms of the Creative Commons Attribution 4.0 International License (http://creativecommons.org/licenses/by/4.0/), which permits use, sharing, adaptation, distribution and reproduction in any medium or format, as long as you give appropriate credit to the original author(s) and the source, provide a link to the Creative Commons license and indicate if changes were made.

The images or other third party material in this chapter are included in the chapter's Creative Commons license, unless indicated otherwise in a credit line to the material. If material is not included in the chapter's Creative Commons license and your intended use is not permitted by statutory regulation or exceeds the permitted use, you will need to obtain permission directly from the copyright holder. 